\title{
Utility of Different Silkworm (Bombyx mori L.) Residues for Cultivation of Button Mushroom
}

\author{
R. Narayana Reddy ${ }^{1^{*}}$, K.G. Banuprakash ${ }^{1}$, T.H. Shankarappa ${ }^{2}$ and B.C. Mallesha ${ }^{1}$ \\ ${ }^{1}$ University of Agricultural Sciences, Bangalore, Karnataka, India \\ ${ }^{2}$ University of Horticultural Sciences, Bagalkot, Karnataka, India \\ *Corresponding author
}

\section{A B S T R A C T}

\begin{tabular}{|l|}
\hline Ke y w o r d s \\
Button mushroom, \\
Silkworm leaf litter, \\
Silk worm excreta, \\
Composting \\
\hline Article Info \\
\hline $\begin{array}{l}\text { Accepted: } \\
\text { 07 March } 2018 \\
\text { Available Online: } \\
\text { 10 April } 2018\end{array}$ \\
\hline
\end{tabular}

Different silkworm residues in combination with paddy straw were evaluated for button mushroom (Agaricus bisporus Lange) production. The substrate was prepared by substituting silk worm leaf litter, silk worm excreta and spent silk moth residue with paddy straw at 25 and 50 percents. The yield and bio-efficiency of button mushroom was found to be highest in control treatment, paddy straw $(927 \mathrm{~g}$ per $5.00 \mathrm{~kg}$ substrate and $61.80 \%$, respectively) and the yield was ranged between 890 and $760 \mathrm{~g}$ per $5.00 \mathrm{~kg}$ substrates prepared with paddy straw in combination with silk worm leaf litter, silk worm excreta and spent silk moth residue. Nutritive value of mushrooms showed that the protein and fat contents were high in the mushrooms grown on substrate combination of paddy straw plus spent residue of silk moth $(29.50 \%$ and 4.70$)$. The total sugar was high in the treatment, paddy straw supplemented with silk worm leaf litter (28\%). During the composting it was observed that the microbial counts like bacteria, fungi and actinomycete had increased up to $21^{\text {st }}$ day of compost preparation and decreased thereafter, while the contents of cellulose and lignin had decreased with the progress of composting.

\section{Introduction}

Sericulture offers a wide range of by-products, which have diverse utility, either by direct or indirect way in agriculture and rural cottage industry as well. Mulberry shoots are used as fuel source and also for paper making, fruits for jam, juice and wine preparation (Reddy et al., 2011). Components like chlorophyll, carotene, phytol and pectin are extracted from the silkworm faeces for use in the manufacture of edible colours, candy, wine, ice-creams and medicines for gastric, ulcer, liver and blood diseases (Aruga, 1994). Silkworm litter is used as feed for cattle, sheep and goats and the excreta for biogas production (Somanna, 1995). Silkworm pupae are utilized in the extraction of oil, which finds its usage in soaps, paints, etc. The pupal powder has amino acids, vitamins etc., which is used as feed for poultry, fish, swine, cattle and as manure. The dead pupae along with larvae and moths are used in organic composting and excreta and silkworm litter is used in vermiculture (Das et al., 1997).

The sericulture waste is a good source for composting with mixed plant residues 
(Sharma et al., 1999) and the mulberry stem can be a source of oyster mushroom production. Several researchers substituted the byproducts of sericulture, mainly the stem with paddy straw in the cultivation of oyster mushroom (Madan and Vasudevan, 1989; Reddy et al., 2000) but the utility of various sericulture wastes in the cultivation of button mushroom is still to be evaluated and exploited. Mushroom is a rich source of protein, vitamins and minerals, which provide nutritional security, economic stability and employment to rural people (Royse, et al., 2016). Agaricus mushroom is an efficient lignin degrader that can be grown on different lignocellulosic wastes (Navi et al., 2011; Reddy et al., 2011). Looking into the availability of large quantities of sericulture wastes in other words residue in and around the Bangalore region we have tried the possibilities of utilizing the sericulture residue for button mushroom (Bombyx mori L.) cultivation.

\section{Materials and Methods}

The study was conducted at mushroom house, College of Agriculture, University of Agricultural Sciences, Bangalore. The different residues obtained after rearing mulberry silk worm and production of silk were subjected for their possibilities of Agaricus mushroom production. The silkworm litter is mixed in different combination with paddy straw and chicken manure to prepare compost (Reddy et al., 2011). The standard compost (control) was prepared by following long method of natural fermentation, using the substrates paddy straw, chicken manure, wheat bran and gypsum in the ratio of $100.0 \mathrm{~kg}: 15.0 \mathrm{~kg}: 5.0$ $\mathrm{kg}: 3.0 \mathrm{~kg}$ respectively and this recipe formed the 100 per cent concentration of the substrates. For the treatments, the paddy straw and chicken manure were substituted with other residues. The silkworm leaf litter 100 $\mathrm{kg}$, silkworm excreta $15 \mathrm{~kg}$ and spent silk moth $5 \mathrm{~kg}$ formed 100 per cent concentration in the study.

The compost was prepared on a clean composting platform after disinfecting with $2 \%$ formalin. The base material, paddy straw was spread on the floor to a height of 25 to 30 $\mathrm{cm}$, made wet by spraying water and turned using forked iron rod. The wetting and turning continued for 5 days and after complete wetting, stacked for $24 \mathrm{~h}$. All other recipe materials were added to the wet straw as per the treatments, sprinkled with water and composted. On $6^{\text {th }}$ day the first turning was given to ensure uniform mixing and composting. Second, third, fourth, fifth sixth and seventh turnings were given on $10^{\text {th }}, 13^{\text {th }}$, $16^{\text {th }}, 19^{\text {th }}, 22^{\text {nd }}, 25^{\text {th }}$ days at an interval of 3 days. The compost was ready by $28^{\text {th }}$ day, had 70 per cent moisture and it was used for mushroom production.

The method outlined by Pandey and Tewari (1993) was followed for the mushroom cultivation. The composts were processed by autoclaving at $121^{\circ} \mathrm{C}$ for $3 \mathrm{~h}$ and allowed to cool by spreading over polythene sheet. Individual composts were packed separately into polythene bags of $15 \times 20 \mathrm{~cm}$ and 150 gauges; with inter spread layers of spawn at 10 $\mathrm{cm}$ and $5 \mathrm{~cm}$ from top of the cover at the rate of $50 \mathrm{~g}$ per $5 \mathrm{~kg}$ compost. The bags were arranged on the iron racks by covering with newspaper on top. Watering was done on the newspaper. The relative humidity of 80 to 85 per cent and temperature of $26 \pm 2{ }^{\circ} \mathrm{C}$ were maintained. After two weeks of spawn run period, when compost was fully covered by mycelium, the newspaper was removed and casing was done by covering the compost with casing material to a thickness of 2 inches. The casing material was prepared from FYM and garden soil in the ratio of $1: 1$. The temperature was lowered to $18^{\circ} \mathrm{C} \pm 2^{\circ} \mathrm{C}$ and fresh air with 85 to 90 per cent relative humidity was 
maintained. The changes resulted in initiation of pin heads and during this period mist watering was done. When mushrooms were at pea size, little heavy watering was done (Reddy et al., 2011). Mushrooms appeared in flushes between 3 and 5 days duration and they are harvested at an interval of 7 to 10 days. Likewise, 4 to 6 harvests were done from 4 to 8 weeks. The yield of sporophores was expressed as g per $5 \mathrm{~kg}$ dry substrate and bio-efficiency of the substrate was calculated.

Nutrients in the substrate such as nitrogen, phosphorous and potassium were estimated before and after cropping; microbial counts like bacteria, fungi and actinomycetes, cellulose and lignin contents in the compost at different stages of composting, yield and nutritional status of mushrooms produced in the above mentioned treatments were estimated. Nitrogen was determined by Kjeldhal method as outlined by Bremmener (1979). Phosphorus and potassium was estimated by the procedure given by Jackson (1973). Cellulose was by calorimetric method using anthrone reagent and lignin by aciddetergent method as outlined by Sadasivam and Manickam (1996). The protein (Jackson, 1973), carbohydrates, fibre and fat (Sadasivam and Manickam, 1996) were estimated to determine the nutritional status of mushroom.

\section{Results and Discussion}

The nutrient status in the recipe made for the composting had shoved variation before and after fermentation. Nitrogen was found to be significantly highest in the treatment $\mathrm{T}_{3}$ with 4.56 per cent followed by $\mathrm{T}_{2}(4.56 \%), \mathrm{T}_{7}$ $(4.18 \%)$ and was least in control i.e., $\mathrm{T}_{1}$ $(3.51 \%)$ before cropping. After cropping the nitrogen content had increased slightly in the treatments and it was highest in $\mathrm{T}_{3}(4.85 \%)$ followed by $\mathrm{T}_{2}(4.63 \%), \mathrm{T}_{7}(4.20 \%)$ and least in $\mathrm{T}_{1}(3.63 \%)$. The phosphorus content also varied in the treatments, it was least in control
$\mathrm{T}_{1}(3.00 \%)$ and ranged from 3.00 to 4.69 per cent in treatments. The highest phosphorous content was observed in the treatment $\mathrm{T}_{3}(4.69$ $\%$ ) followed by $\mathrm{T}_{2}(4.53 \%)$ and $\mathrm{T}_{7}(4.11 \%)$. After cropping the phosphorus content slightly increased in the substrates. Similarly the potassium ranged from 1.67 to 2.52 per cent and 1.74 to 2.58 per cent before and after cropping, respectively. The potassium content did not vary much, but has increased slightly after the cropping (Table 1).

The increase in NPK content in compost may be due to the accumulation of mycelial mass in the strata (Chang, 1990; Reddy et al., 2000) as well as the reduction in the biomass after composting resulting in mineralization of the nutrients (Cortez, 1996; Bechara et al., 2005; Shankarappa et al., 2015). The microbial counts like bacteria, fungi and actinomycetes were least on zero days and increased in population up to $28^{\text {th }}$ day of composting (Table 2). On $28^{\text {th }}$ day of composting the population, the bacterial counts ranged between 8.30 and $9.57 \times 10^{6} \mathrm{CFU}$ per gram, it was higher than fungi (7.47 and $8.63 \times 10^{4}$ CFU per gram and actinomycetes (7.23 and $8.90 \times 10^{2} \mathrm{CFU}$ per gram. The results suggest that the bacterial counts were higher than fungi and actinomycetes perhaps due to their fast multiplication rate and their small size (Rainey et al., 1990; Nugaeva, 2000; Reddy et al., 2011).

The cellulose and lignin context in the substrates was found to be varied significantly in all the treatments (Table 3). The cellulose and lignin had decreased drastically from 0 to $28^{\text {th }}$ day of composting because of natural aerobic fermentation caused by mixture of natural microflora present in the substrates. The highest cellulose content was observed in the treatments $\mathrm{T}_{8}(27.83$ and $25.33 \%)$ followed by $\mathrm{T}_{1}(27.60$ and $25.33 \%)$ and $\mathrm{T}_{4}$ (27.57 and $24.67 \%$ ), before and after decomposition respectively. 
The substrate combinations exploited for the purpose of compost making in the experiment are as follows

\begin{tabular}{|c|c|}
\hline $\mathrm{T}_{1}$ & $\begin{array}{l}\text { Paddy straw }(100 \%)+\text { Chicken manure }(100 \%)+\text { wheat bran }(100 \%)+\text { Gypsum } \\
(100 \%) \text { (Control) }\end{array}$ \\
\hline $\mathbf{T}_{2}$ & $\begin{array}{l}\text { Paddy straw }(\mathbf{7 5} \%)+\text { Silkworm leaf litter }(25 \%)+\text { Chicken manure }(100 \%)+\text { wheat } \\
\text { bran }(100 \%)+\text { Gypsum }(100 \%)\end{array}$ \\
\hline$\overline{T_{3}}$ & $\begin{array}{l}\text { Paddy straw }(50 \%)+\text { Silkworm leaf litter }(50 \%)+\text { Chicken manure }(100 \%)+\text { wheat } \\
\text { bran }(100 \%)+\text { Gypsum }(100 \%)\end{array}$ \\
\hline$\overline{T_{4}}$ & $\begin{array}{l}\text { Paddy straw }(100 \%)+\text { Silkworm leaf litter }(25 \%)+\text { Chicken manure }(\mathbf{7 5} \%)+\text { wheat } \\
\text { bran }(100 \%)+\text { Gypsum }(\mathbf{1 0 0 \%})\end{array}$ \\
\hline$\overline{T_{5}}$ & $\begin{array}{l}\text { Paddy straw }(\mathbf{7 5} \%)+\text { Silkworm leaf litter }(\mathbf{2 5} \%)+\text { Silkworm excreta }(25 \%)+\text { Chicken } \\
\text { manure }(\mathbf{7 5} \%)+\text { Wheat bran }(\mathbf{1 0 0} \%)+\text { Gypsum }(\mathbf{1 0 0 \%})\end{array}$ \\
\hline $\mathrm{T}_{6}$ & $\begin{array}{l}\text { Paddy straw }(\mathbf{7 5} \%)+\text { Silkworm leaf litter }(25 \%)+\text { Spent silk moths }(50 \%)+\text { Chicken } \\
\text { manure }(50 \%)+\text { Wheat bran }(100 \%)+\text { Gypsum }(100 \%)\end{array}$ \\
\hline $\mathrm{T}_{7}$ & $\begin{array}{l}\text { Paddy straw }(50 \%)+\text { Silkworm leaf litter }(50 \%)+\text { Spent silk moths }(50 \%)+\text { Chicken } \\
\text { manure }(50 \%)+\text { Wheat bran }(100 \%)+\text { Gypsum }(100 \%)\end{array}$ \\
\hline $\mathrm{T}_{8}$ & $\begin{array}{l}\text { Paddy straw }(100 \%)+\text { Silkworm excreta }(25 \%)+\text { Spent silk moths }(25 \%)+\mathrm{Cl} \\
\text { manure }(50 \%)+\text { Gypsum }(100 \%)\end{array}$ \\
\hline
\end{tabular}

Table.1 NPK contents of compost before and after cropping of button mushroom on various silkworm based substrates

\begin{tabular}{|c|c|c|c|c|c|c|}
\hline \multirow{2}{*}{ Treatments } & \multicolumn{3}{|c|}{ Before cropping (\%) } & \multicolumn{3}{c|}{ After cropping (\%) } \\
\hline & $\mathbf{N}$ & $\mathbf{P}$ & $\mathbf{K}$ & $\mathbf{N}$ & $\mathbf{P}$ & $\mathrm{K}$ \\
\hline $\mathrm{T}_{1}$ & 3.51 & 3.00 & 1.67 & 3.63 & 3.05 & 1.74 \\
\hline $\mathrm{T}_{2}$ & 4.56 & 4.53 & 2.43 & 4.63 & 4.59 & 2.52 \\
\hline $\mathrm{T}_{3}$ & 4.79 & 4.69 & 2.52 & 4.85 & 4.75 & 2.58 \\
\hline $\mathrm{T}_{4}$ & 3.47 & 3.42 & 1.81 & 3.56 & 3.48 & 1.85 \\
\hline $\mathrm{T}_{5}$ & 3.64 & 3.50 & 1.97 & 3.68 & 3.62 & 2.09 \\
\hline $\mathrm{T}_{6}$ & 4.01 & 3.98 & 2.13 & 4.08 & 4.03 & 2.15 \\
\hline $\mathrm{T}_{7}$ & 4.18 & 4.11 & 2.15 & 4.20 & 4.19 & 2.21 \\
\hline $\mathrm{T}_{8}$ & 4.07 & 3.90 & 2.16 & 4.13 & 3.95 & 2.24 \\
\hline Sem \pm & $\mathbf{0 . 2 9}$ & $\mathbf{0 . 5 2}$ & $\mathbf{0 . 5 7}$ & $\mathbf{0 . 4 4}$ & $\mathbf{0 . 2 4}$ & $\mathbf{0 . 6 3}$ \\
\hline $\mathrm{CD}$ at 5 \% & $\mathbf{0 . 6 5}$ & $\mathbf{1 . 1 4}$ & 1.19 & $\mathbf{0 . 9 6}$ & $\mathbf{0 . 5 3}$ & 1.38 \\
\hline
\end{tabular}


Table.2 Microbial counts in the compost at different stages of composting of various substrates

\begin{tabular}{|c|c|c|c|c|c|c|c|c|c|}
\hline \multirow{3}{*}{ Treatments } & \multicolumn{3}{|c|}{ Bacteria (CFU $10^{6} \mathrm{~g}^{-1}$ ) } & \multicolumn{3}{|c|}{ Fungi (CFU $10^{4} \mathrm{~g}^{-1}$ ) } & \multicolumn{3}{|c|}{ Actinomycetes (CFU $10^{2} \mathrm{~g}^{-1}$ ) } \\
\hline & \multicolumn{3}{|c|}{ Days } & \multicolumn{3}{|c|}{ Days } & \multicolumn{3}{|c|}{ Days } \\
\hline & $\mathbf{0}$ & 14 & 28 & $\mathbf{0}$ & 14 & 28 & $\mathbf{0}$ & 14 & 28 \\
\hline $\mathbf{T}_{1}$ & 3.93 & 7.47 & 8.30 & 5.07 & 7.33 & 7.47 & 4.31 & 6.60 & 7.23 \\
\hline$T_{2}$ & 4.93 & 8.37 & 8.97 & 4.27 & 7.47 & 7.70 & 5.31 & 7.20 & 7.57 \\
\hline$T_{3}$ & 4.40 & 9.23 & 9.53 & 3.90 & 7.47 & 7.83 & 5.13 & 7.40 & 7.67 \\
\hline $\mathrm{T}_{4}$ & 3.60 & 9.13 & 9.17 & 4.47 & 8.00 & 8.33 & 3.87 & 6.20 & 6.53 \\
\hline$T_{5}$ & 3.67 & 7.83 & 8.60 & 3.97 & 8.13 & 8.20 & 3.89 & 7.47 & 7.70 \\
\hline$T_{6}$ & 3.80 & 7.87 & 8.63 & 4.30 & 7.80 & 8.00 & 4.27 & 7.47 & 7.67 \\
\hline$T_{7}$ & 3.60 & 9.10 & 9.40 & 4.70 & 8.00 & 8.17 & 4.20 & 8.67 & 8.90 \\
\hline$T_{8}$ & 4.53 & 9.10 & 9.57 & 5.50 & 8.53 & 8.63 & 4.84 & 7.80 & 8.50 \\
\hline Sem \pm & 0.28 & 0.25 & 0.59 & 0.33 & 0.19 & 0.24 & 0.21 & 0.58 & 0.64 \\
\hline CD at $5 \%$ & 0.62 & 0.65 & 1.29 & 0.74 & 0.42 & 0.54 & 0.48 & 1.26 & 1.39 \\
\hline
\end{tabular}

Table.3 Cellulose and lignin contents in the compost at different stages of composting of various substrates

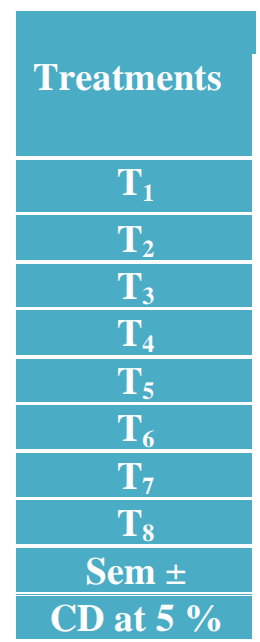

\begin{tabular}{|c|c|c|c|c|c|}
\hline \multicolumn{3}{|c|}{ Cellulose (\%) } & \multicolumn{3}{|c|}{ Lignin (\%) } \\
\hline & Days & & & Days \\
\hline $\mathbf{0}$ & $\mathbf{1 4}$ & $\mathbf{2 8}$ & $\mathbf{0}$ & $\mathbf{1 4}$ & $\mathbf{2 8}$ \\
\hline 27.83 & 25.33 & 24.33 & 24.00 & 22.33 & 20.33 \\
\hline 17.47 & 15.83 & 15.17 & 21.67 & 20.33 & 18.33 \\
\hline 20.10 & 17.53 & 16.87 & 19.33 & 18.67 & 16.67 \\
\hline 27.57 & 25.33 & 24.67 & 24.00 & 22.67 & 20.67 \\
\hline 25.53 & 22.00 & 21.33 & 22.00 & 21.00 & 12.67 \\
\hline 24.97 & 22.67 & 22.00 & 22.00 & 21.00 & 15.67 \\
\hline 20.23 & 18.00 & 17.33 & 20.00 & 19.33 & 14.33 \\
\hline 27.60 & 25.33 & 24.67 & 24.33 & 22.67 & 20.67 \\
\hline $\mathbf{0 . 5 4}$ & $\mathbf{0 . 5 6}$ & $\mathbf{0 . 5 5}$ & $\mathbf{0 . 6 9}$ & $\mathbf{0 . 4 9}$ & $\mathbf{2 . 6 1}$ \\
\hline $\mathbf{1 . 1 7}$ & $\mathbf{1 . 2 2}$ & $\mathbf{1 . 2 0}$ & $\mathbf{1 . 5 2}$ & $\mathbf{1 . 0 8}$ & $\mathbf{5 . 6 9}$ \\
\hline
\end{tabular}

Table.4 Button mushroom yield and nutrition status as influenced by various silkworm based substrates

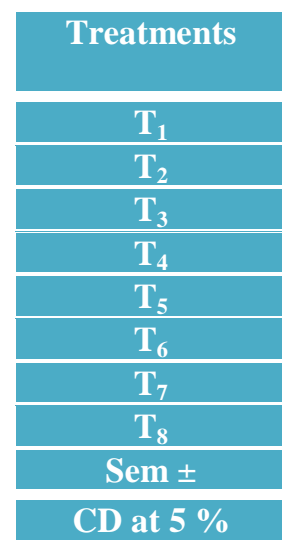

\begin{tabular}{|c|}
\hline $\begin{array}{c}\text { Button mushroom } \\
\text { yield }(\mathrm{g})\end{array}$ \\
\hline 908.67 \\
\hline 845.67 \\
\hline 837.33 \\
\hline 856.67 \\
\hline 795.94 \\
\hline 813.37 \\
\hline 814.67 \\
\hline 857.33 \\
\hline $\mathbf{5 . 3 3}$ \\
\hline $\mathbf{1 1 . 6 2}$ \\
\hline
\end{tabular}

\begin{tabular}{|c|}
\hline $\begin{array}{c}\text { Bio-efficiency } \\
(\%)\end{array}$ \\
\hline 60.57 \\
\hline 56.37 \\
\hline 55.82 \\
\hline 57.11 \\
\hline 53.06 \\
\hline 54.72 \\
\hline 54.31 \\
\hline 57.15 \\
\hline- \\
\hline
\end{tabular}

\begin{tabular}{|c|}
\hline $\begin{array}{c}\text { Proteins } \\
(\%)\end{array}$ \\
\hline 26.54 \\
\hline 29.75 \\
\hline 29.89 \\
\hline 27.71 \\
\hline 27.93 \\
\hline 29.57 \\
\hline 28.94 \\
\hline 28.45 \\
\hline $\mathbf{0 . 4 9}$ \\
\hline 1.08 \\
\hline
\end{tabular}

\begin{tabular}{|c|c|}
\hline $\begin{array}{c}\text { Total sugars } \\
(\%)\end{array}$ & Fat (\%) \\
\hline 51.00 & 5.96 \\
\hline 50.67 & 4.62 \\
\hline 50.00 & 4.68 \\
\hline 49.67 & 4.85 \\
\hline 50.67 & 4.64 \\
\hline 53.33 & 3.76 \\
\hline 52.30 & 4.29 \\
\hline 52.77 & 4.27 \\
\hline $\mathbf{2 . 0 3}$ & $\mathbf{0 . 0 8}$ \\
\hline 4.43 & 0.17 \\
\hline
\end{tabular}

\begin{tabular}{|c|}
\hline Fibre (\%) \\
\hline 9.75 \\
\hline $\mathbf{8 . 8 9}$ \\
\hline $\mathbf{8 . 8 1}$ \\
\hline 8.75 \\
\hline 8.65 \\
\hline 8.66 \\
\hline 8.64 \\
\hline 9.20 \\
\hline 0.06 \\
\hline 0.14 \\
\hline
\end{tabular}


Similar trends were also observed in all these treatments for lignin content. The results suggest that where ever the paddy straw was used at $100 \%$ concentration had highest cellulose and lignin contents as against its substitution, because of the nature of the paddy straw used in the composting. During the fermentation the fermentative microflora may have secreted the hydrolytic enzymes required for degradation of cellulose and lignin such as cellulases and ligninases (Shankarappa et al., 2015; Shankarappa et al., 2016).

The yield of button mushroom due to different treatments and their bio-efficiency had varied considerably (Table 4). They were high in $\mathrm{T}_{1}$ (908.67 g and $620.57 \%$, respectively) and low in $\mathrm{T}_{5}$ (795.94 $\mathrm{g}$ and $53.06 \%$, respectively). The control yield was highest in the controlled treatment $T_{1}$, Where 100 per cent paddy straw was used along with other components and the treatments substituted with sericulture residues although produced considerable amount of mushroom yield it was significantly low, suggesting that the sericulture residues such as silk worm leaf litter, silkworm excreta and spent silk moth are not efficient compared to control. Differences in respect of both yield and bioefficiency might be attributed to inherent capacity of the composts to release nutrients, present in their respective substrates (Madan and Vasudevan, 1989; Poppe, 2000; Baruah et al., 2000).

Nutritive value of mushrooms was significantly influenced by the type of composts used for their cultivation (Table 4). Proteins were higher in $\mathrm{T}_{3}(29.89 \%)$ and least in $\mathrm{T}_{1}(26.54 \%)$ i.e., control. In other treatments proteins ranged from 27.71 to 29.89 per cent which were higher than the control. The lowest sugar content 50.00 $\%$ was observed in $\mathrm{T}_{4}(49.67 \%)$ and it was highest in $\mathrm{T}_{8}(52.77 \%)$. The lowest and highest fat content was observed in $\mathrm{T}_{6}(3.76 \%)$ and $\mathrm{T}_{1}$ $(5.96 \%)$ respectively. The lowest and highest fibre content was observed in $\mathrm{T}_{7}\left(8.64 \%\right.$ and $\mathrm{T}_{1}$ $(5.96 \%)$. These nutrients had showed a range, total sugars ( 49.67 to $53.33 \%$ ), fat (3.76 to 5.96 $\%)$ and fibre contents (8.64 to $9.75 \%)$. The variation exhibited with respective values of button mushrooms grown on different composts might be due to the varied composition of nutrients in different substrates, which might have contributed to the nutritional profile of mushrooms (Madan and Vasudevan, 1989; Poppe, 2000).

\section{References}

Aruga, H. 1994. Priciples of Sericulture. Oxford and IBH Pub. Co. Pvt. Ltd., New Delhi, pp. 358 - 365.

Baruah, A. M., Reddy, D.N.R. and Mallesh, B.C. 2000. Potentiality of Eri silkworm wastes in Oyster mushroom. In: Nonmulberry Sericulture, Silk Industry, Sericulture Economics and Extension (Eds. K.P. Chinnaswamy, R. Govindan, N.K. Krishnaprasad and D.N.R. Reddy). Proc. Natl. Sem. Tropic. Seric., UAS, Bangalore, pp. $86-87$.

Bechara, M., Heinemann, P., Walker, P. and Romaine, C.P. 2005. Cultivation of Agaricus bisporus on a mixture of cereal grain spawn and delayed-release nutrient supplement. Mush. News, 53(8): 6-10.

Bremmener, J. M. 1979. Total Nitrogen. In: Methods of Soil Analysis, (Ed. C. A. Black), Agronomy series No. 9, Part 2, American Society of Agronomy, Madison, Wiscon, pp. 1149 - 1179.

Chang, S.T. 1990. Future trends in cultivation of alternative mushrooms. Mushroom J., 215: $422-423$.

Cortez, J., Demard, J. M., Bottner, P. and Jocturnonlozer, L.1996. Decompostion of Mediterranean leaf litters, a microorganisms experiment investigating relationship between decomposition rate and litter quality. Soil Biol. Biochem., 28 (4/5): 443 - 452.

Das, P.K., Bhogesha, K., Sundareshwaran, P., Madhava Rao, Y. and Sharma, D.D. 1997. Vermiculture: Scope and potentiality in Sericulture. Indian Silk, 36 (2): $23-26$. 
Jackson, M.L. 1973. Soil Chemical Analysis. Prentice Hall India Pvt. Ltd., New Delhi, P. 498.

Madan, M. and Vasudevan, P.V. 1989. Silkworm litter use as nitrogen replacement for crop cultivation and substrate for mushroom cultivation. Biol. Wastes, 27: 201- 216.

Navi, V., Patil, C. R., Shankarappa, T. H. and Naik, S. T. 2011. Suitability of agroforest residues for cultivation of Pleurotus florida. Environ. Ecol., 29(1): 179-182.

Nugaeva, N. 2000. Micromycetes in the substrate and the hyphosphere of Agaricus bisporus. J. Hort. Sci. Biotechnol., 75: 417 - 424.

Pandey, M. and Tewari, R.P. 1993. Cultivation of milky mushroom (Calocybe indica). Mushroom Infom., 5: 5 - 11.

Poppe, J. 2000. Use of agricultural waste materials in the cultivation of mushrooms. In: Proc. of $15^{\text {th }}$ International Congress on the Science and Cultivation of Edible fungi, Maastricht, Netherlands, pp. $3-23$. Rainey, P.B., Cole, A.L.J., Fermor, T.R. and Wood, D.A.1990. A model system for examining involvement of bacteria in basidiome initiation of Agaricus bisporus. Mycol. Res., 94 (2): 191 - 195.

Reddy, R. N., Shankar, S., Mallesha, B. C. and Santhosh, G. P. 2011. A novel approach to silkworm litter management. In: Golden Jubilee Conference- Sericulture Innovations: Before and Beyond 2011, Proceedings of the national conference, 28-29 ${ }^{\text {th }}$ Jan. 2011. CFTRI, Mysore, 481485 .
Reddy, R.N., Reddy, D.N.R. and Subbarayappa, C.T. 2000. Cultivation of Oyster mushroom on eri silkworm litter. Int. J. Wild Silkmoth and Silk, 5: $263-265$.

Royse, D. J., Baars, J. and Tan, Q. 2016. Current overview of mushroom production in the world. In: Zied DC, editor. Edible and medicinal mushrooms: technology and applications. New York: Wiley.

Sadasivam, S. and Manickam, A. 1996. Biochemical Methods. New age International Pvt. Ltd., Second Edn., P.196.

Shankarappa, T. H., Geeta, G. S., Manju, M. J., Indi, D V., Alagawadi, A. R. and Krishnaraj, P. U. 2016. AgroresiduesAlternate cheap substrates for fermentable sugar production by crude enzymes of different fungi. Environ. Ecol. 34 (4C): $1881-1889$.

Shankarappa, T. H., Geeta, G. S., Narotham Prasad, B. D., Doddagoudar, C. K. and Alagawadi, A. R. 2015. Biological pretreatment of agroresidues with lignolytic fungi for delignification and recovery of cellulose and hemicellulose. Int. J. Curr. Microbiol. App. Sci. 4(9): 2230.

Sharma, S., Mathur, R. C. and Vasudevan, P. 1999. Composting silkworm culture waste. Compost Science and Utilization. 7(2):74-81.

Somanna, D. 1995.Comparative production of biogas from mulberry silkworm excreta and other substrates. M.Sc. (Seri.) Thesis, UAS, Bangalore, P. 82.

\section{How to cite this article:}

Narayana Reddy, R., K.G. Banuprakash, T.H. Shankarappa and Mallesha, B.C. 2018. Utility of Different Silkworm (Bombyx mori L.) Residues for Cultivation of Button Mushroom. Int.J.Curr.Microbiol.App.Sci. 7(04): 473-479. doi: https://doi.org/10.20546/ijcmas.2018.704.055 